\title{
POSSIBILITIES OF EFFECTIVE INERTISATION OF SELF-HEATING PLACES IN GOAF OF LONGWALL IN HARD COAL MINES
}

\author{
Nikodem SZLAZZAK, Kazimierz PIERGIES \\ AGH University of Science and Technology
}

\begin{abstract}
:
Underground fires in coal mines belong to the most common hazards, the exposure to which frequently requires long term and costly rescue operations. It is mainly connected with the specific character of underground excavations which have limited volume. This makes the maximum permissible concentration of harmful gases rapidly exceeded and may also cause changes in air flow direction. The most certain way of improving a safety situation in Polish coal mining industry is taking early prevention steps. One of the prevention methods is inertisation of the atmosphere in longwall goaf. These activities rely on partial or total replacement of air or combustible atmosphere by inert gas. Thanks to them the risk of spontaneous fires hazard and gas explosion decreases. The main reason for the use of inert gases is to reduce the oxygen content to a limit which prevents further development of fire. This article presents methods for assessing inert gas to replace oxygen in the atmosphere in goaf.
\end{abstract}

Key words: inertisation in goaf of longwall with caving, gas concentration in goaf, underground fire, fighting the fire

\section{INTRODUCTION}

In many cases underground fires have been the reason for mining hazards and tragic disasters. Fire smokes are the reason why the permissible concentration of harmful gases is exceeded; they can lead to dangerous changes in the direction of air flow and limited visibility, which has a very important influence on miners who need to be evacuated from endangered longwall panels.

In underground mining two types of fires can be distinguished:

- open fires - started due to external factors,

- spontaneous fires - started due to internal factors, that is due to coal or ore self-heating process.

Spontaneous fires are most common in underground coal mines and goaf of longwalls with caving is most sensitive to this kind of fire. Controlling the process of spontaneous combustion of coal is commonly regarded as fire prevention.

The necessary condition for an underground fire to start and continue is a simultaneous occurrence of: combustible material, adequate oxygen concentration in mine air and relatively high temperature so that a fire can be started. If at least one of those conditions is absent a fire cannot be started.

The following elements can be regarded as spontaneous fire prevention methods:

- limiting coal losses in goaf,

- quick rate of face advance and short period of closing it down (shorter than 2 months),

- sealing goaf with chemical foam or mineral foam, fly ash or flotation tailings,

- using inertisation,

- using antipyrogens,

- limiting volumetric air flow rate to longwall face,
- limiting air flow to goaf by balancing aerodynamical potentials,

- using screens limiting air flow to goaf,

- filling goaf with mine water.

Mining without leaving coal remnants in goaf is practically not possible; it is also difficult to remove heat that is produced during an oxidation process. That is why it is necessary to eliminate or reduce considerably oxygen concentration in air of goaf of longwall with caving in hard coal mines. Inertisation of mine air is helpful in that. It consists in partial or total replacement of air or combustible atmosphere with an impartial gas. Thanks to that, spontaneous fire risk as well as gas explosion hazard are reduced.

\section{ESTIMATION OF INERTISATION EFFECTIVENESS}

Possibilities of controlling spontaneous fires in goaf of operating longwalls with caving are limited. Inertisation is one of the prevention methods, which is not always effective.

Accorging to Polish mining regulations only nitrogen and carbon dioxide can be used for the inertisation of goaf of operating longwalls with caving [3].

Different factors can have an influence on the effectiveness of using inert gases. Works $[2,10]$ present the factors that have a direct influence:

1. Quite accurate determination of the place of coal selfheating process or spontaneous fire.

2. Correct usage of detailed analysis of ventilation conducted in accordance with the distribution of decreases in aerodynamical potentials, mining, technical and organizational conditions around operating workings or old workings.

3. Sealing off the old workings. 
4. Taking into consideration all possible connections of sealed the old workings or longwall goaf with other ventilation operating mining workings and goaf in other seams.

5. Changes in barometric pressure.

6. Right choice of inertisation technology, speed of starting machinery for dosing inert gas.

7. Continuous dosing of inert gases to hazardous areas.

8. Simultaneous usage of other already used methods for fire or gas control, in particular:

- extra sealing of goaf, isolation stoppings, sealing fissures,

- silting, flooding mine workings or longwall goaf,

- current control and analysis of distribution of decreases in aerodynamical potentials in hazardous areas.

9. Possibilities of quick cooling of spontaneous heating or fire place.

The aim of inertisation is to eliminate or reduce considerably oxygen concentration in air, which is supposed to prevent fires or to stop them. The minimum oxygen concentration to maintain coal combustion, obtained during research is $2 \%$ [6]. Generally, it is assumed that if oxygen concentration falls below $2 \%$ the process of solid fuel combustion will not take place [13]. During the research into oxidation of samples from a few seams in Polish coal mines it was concluded that oxygen concentration safe for a spontaneous fire in goaf or isolation areas ranges from about $5 \%$ to about $9 \%$ [1].

Inert gas should be dosed to goaf as close to the place of potential coal spontaneous heating as possible. The exact location of this place during longwall movement is not possible.

During low ventilation intensity, goaf is filled with inert gases hindering a spontaneous heating process. In turn, very high ventilation intensity results in heat outflow produced during oxidation process and it also prevents a coal spontaneous heating process. The least favourable is the middle range as there is a sufficient air flow for a spontaneous coal heating to develop and too small air velocity does not ensure the produced heat outflow [8]. In such conditions, heat accumulation, increase in temperature and fire development occur.

On the basis of lab research it was concluded that the most favourable conditions for spontaneous heating of broken coal occur during air flow of $1.9 \mathrm{~m}^{3} / \mathrm{h}$ per $1 \mathrm{~m}^{3}$ of coal [4]. According to [5] most fires start in places where air velocity is lower than $0.5 \mathrm{~m} / \mathrm{s}$. In turn, Russian research shows the range of air velocity, where favourable conditions for coal spontaneous heating occur. The results of the research were confirmed by observations in Polish mines [7]. The range mentioned refers to air velocity ranging from 1.5 to $15 \mathrm{~mm} / \mathrm{s}$. The same range was quoted in later publications $[9,10]$.

Reducing oxygen concentration below $8 \%$ in the area where air velocity ranges from 1.5 to $15 \mathrm{~mm} / \mathrm{s}$ may be a criterion for estimating the effectiveness of inertisation [14]. The state before using inertisation is a good criterion for estimating its effectiveness.

The information concerning air flow zone and oxygen concentration in goaf is important to determine the necessary "depth" of inertisation and its influence on effectiveness. That is why, this kind of information should influence the choice of a method and place of injecting inert gases to goaf.
That is why, it is essential to find a method for calculating air flow distribution and distribution of oxygen concentration in goaf of longwall with caving in hard coal mines after injecting inert gas.

\section{BASIC ASSUMPTIONS OF COMPUTER PROGRAMMES WRITTEN TO SIMULATE AIR FLOW DISTRIBUTION IN GOAF}

Transport of substances inside a porous structure in horizontal goaf in an underground coal mine was taken into consideration. The area is partially filtered by air coming from a mine ventilation system, which flows through roadways. Methane is emitted inside goaf. An additional local nitrogen emission of assumed flow rate dosed through a pipeline inside the goaf was taken into consideration for calculations.

Assuming a laminar character of filtration in longwall goaf through a gaseous medium and the stationary character of the whole process under consideration, local balance of the substance quantity can be expressed in the form of the generalized equation of continuity. Darcy's law is introduced in order to close the set of equations. By inserting apparent velocity, which is velocity over the total area of the cross-section of the medium, into the dependences a differential equation is obtained, on the basis of which pressure area in goaf can be determined.

The variable character of the viscosity of gas mixture and the co-efficient of absolute viscosity of this mixture result from a various character of chemical content penetrating a gaseous medium; however, the permeability of a porous medium is a function of exclusively a horizontal spatial variable parallel to a longer side of the rectangular area under consideration, which results from research [12]. On the basis of the value of the co-efficient of permeability of a porous medium, a local value of open porosity can be estimated, considering roof caving as a layer consisting of solid grains of a determined replacement diameter.

Dirichter's or first-type boundary conditions defining direct values of the functions of excess pressure in goaf as well as molar concentrations of all particular elements of a gas mixture occur on surfaces having contact with air flowing along the gallery. On the remaining boundaries the lack of substance flow through a boundary area is assumed; that is why Neumann's or second-type conditions are obtained.

The designed calculation algorithm is based on the procedure known as Control Volume Method, which was also known in Poland as Elementary Balances Method.

Using the criterion of the most frequently used longwall ventilation systems, computer programmes were written for two different ventilation methods:

- U - ventilation system with retreat mining (Fig. 1a),

- $\mathrm{Y}$ - ventilation system with retreat mining (Fig. 1b).

The possibility of dosing inert gas to goaf area during normal longwall operation was assumed in computer programmes written as a part of work [14]. As nitrogen was used as inert gas most frequently in fire prevention, its usage would be considered. Inert gas can be dosed in a gallery with intake air, being closed down with face advance. This location results from the recommendation that inert gas distribution should be the same as the direction of air flow to goaf [11]. In figures $1 \mathrm{a}$ and $1 \mathrm{~b}$ the possible location of the point of injecting inert gas was marked with an orange segment and a possible location was marked with an orange point. The location of this point is referred to as the distance from goaf line, marked in Fig. 1. 
a)

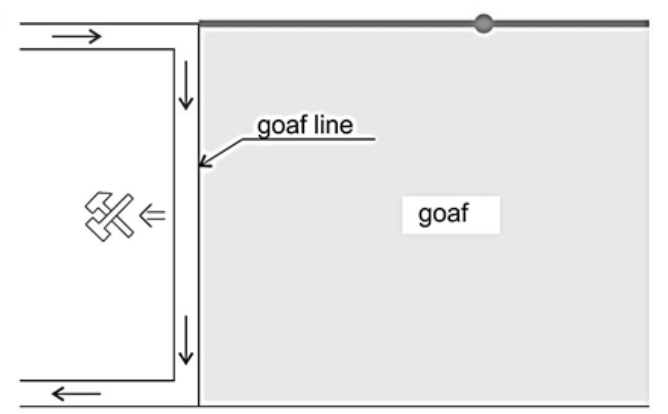

b)

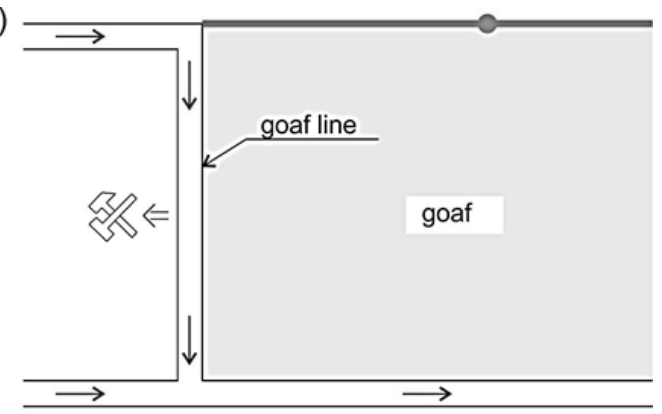

LEGEND

BS $\Leftarrow$ - direction of mining

- intake air

$\longrightarrow$ - return air

- nitrogen dosing point

- the possible location of the point of dosing inert gas

Fig. 1 Ventilation system:

a) „U", b) "Y"

Due to the rectangular shape of the area under consideration (Fig. 2) a Cartesian coordinate system was used. The beginning of the coordinate system $(x=0, y=0)$ overlaps the top left corner of the area and axes are directed respectively: $\mathrm{x}$ - to the left and $\mathrm{y}$ - horizontally down in accordance with the direction of air flow in the roadway. It refers to both analysed variants of computer simulations. Figure 2 presents goaf area of length $b$ and range $a$.

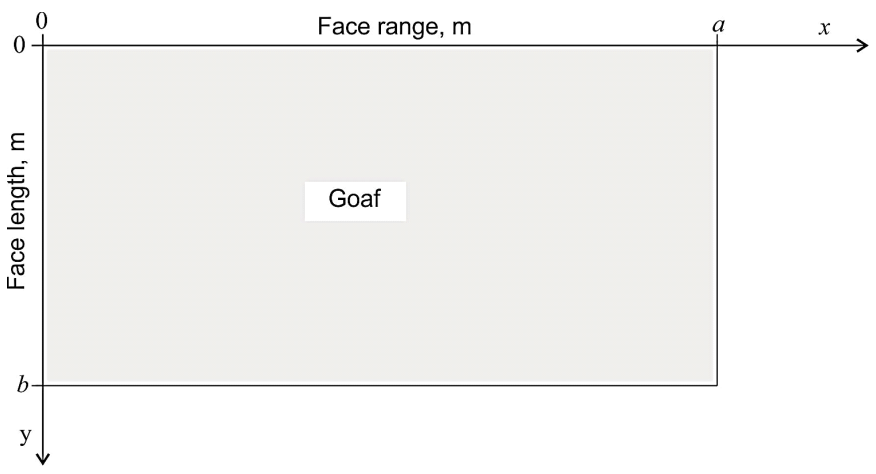

Fig. 2 Goaf area with the adopted Cartesian coordinate system

The following data for calculations can be distinguished:

1. Geometric parameters of roadways:

- face length,

- face height,

- face range,

- height of tailgate or headgate roadway,

- cross-sectional area of roadway.

2. Air physical properties:

- density and viscosity,

- volumetric air flow rate in a longwall's face.

3. Parameters characterising filtration properties of goaf.

4. Losses in pressure drop along airways surrounding goaf:

- for $U$ - ventilation system with retreat mining in longwall,

- for $\mathrm{Y}$ - ventilation system with retreat mining in longwall and headgate.

5. Parameters of inertisation process

- volumetric flow of delivered nitrogen,

- coordinates of the point of injecting nitrogen,

- volumetric flow of methane flowing in.

As a result of computer simulations the following twodimensional discrete physical fields occurring in goaf area are obtained:
- excess pressure field (excess in relation to atmospheric pressure) in porous area, $\mathrm{Pa}$,

- the apparent velocity field of a mixture of gaseous components, $\mathrm{m} / \mathrm{s}$,

- field of the molar concentration of nitrogen and molar ratio of nitrogen $(\%), \mathrm{mol} / \mathrm{m}^{3}$,

- field of molar concentration of methane and molar ratio of methane (\%), $\mathrm{mol} / \mathrm{m}^{3}$,

- field of molar concentration of oxygen and molar ratio of oxygen (\%), $\mathrm{mol} / \mathrm{m}^{3}$.

Written computer programmes make it possible to determine the fields above in two variants with different boundary conditions.

\section{EXAMPLE OF USING WRITTEN COMPUTER PROGRAMMES}

The example refers to goaf of longwall $\mathrm{N}-17 \mathrm{a}$ in seam $328 / 1$ in Coal Mine B [15].

Natural hazards in the longwall panel:

- IV category of methane hazard, forecasted absolute methane-bearing capacity $41,8 \mathrm{~m}^{3}, \mathrm{CH}_{4} / \mathrm{min}$,

- class „B" of coal dust explosion hazard,

- I degree of water hazard,

- III group of coal self-ignition.

Longwall $\mathrm{N}-17$ a was ventilated by $\mathrm{U}$-system; the scheme of the longwall is presented in Figure 3.

The following data were used for calculations:

- face length - $240 \mathrm{~m}$;

- length of longwall panel - $700 \mathrm{~m}$. It was assumed that within the length, the longwall will come across geological disturbances requiring leaving a coal slice in the roof, which while collapsing will create a selfcombustion hazard,

- face height $-2.2 \mathrm{~m}$,

- resistance of roof rock separation - 2.2 MPa;

- volumetric air flow rate in longwall face $-1250 \mathrm{~m}^{3} / \mathrm{min}$,

- methane flow into longwall goaf $-17 \mathrm{~m}^{3} / \mathrm{min}(70 \%$ effectiveness of methane drainage was assumed [15]),

- nitrogen will be dosed from research roadway $\mathrm{N}-17 \mathrm{a}$,

- volumetric nitrogen flow (3 variants) - $10 \mathrm{~m}^{3} / \mathrm{min}$, $20 \mathrm{~m}^{3} / \mathrm{min}, 30 \mathrm{~m}^{3} / \mathrm{min}$; the situation when no nitrogen is dosed was considered as well. Later all the results were compared,

- distance of the point of dosing nitrogen from goaf line $(6$ variants $)-20 \mathrm{~m}, 30 \mathrm{~m}, 40 \mathrm{~m}, 50 \mathrm{~m}, 60 \mathrm{~m}$, $70 \mathrm{~m}$. 


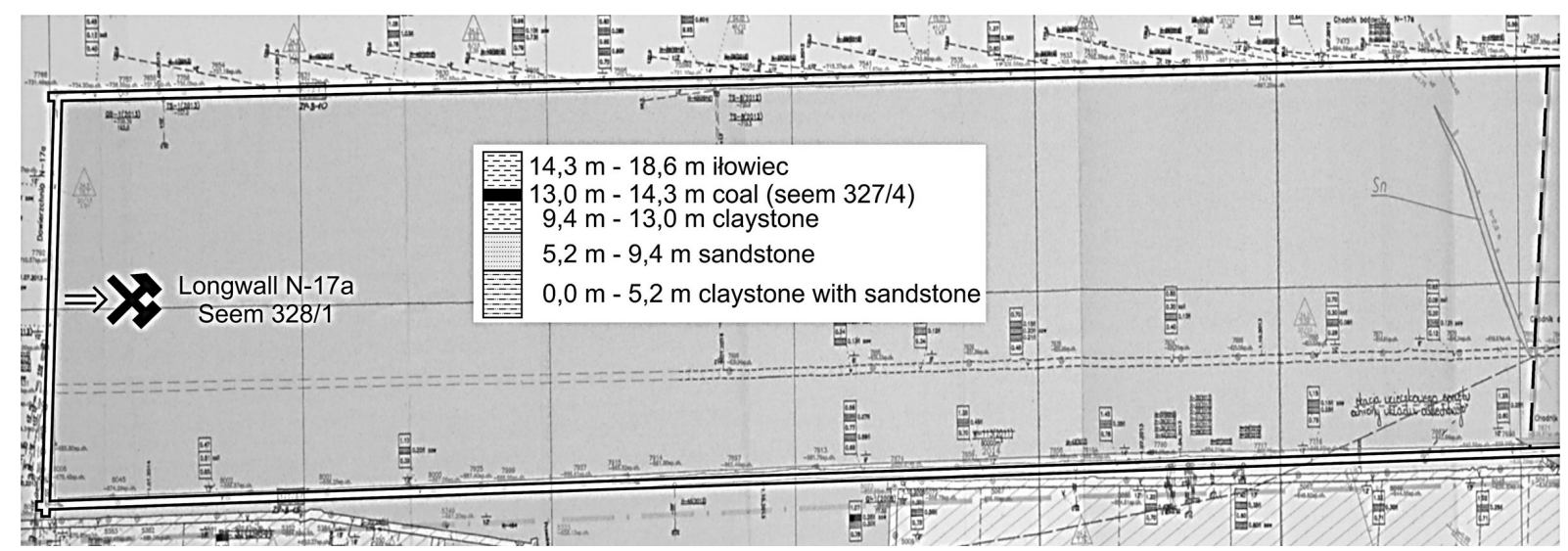

Fig. 3 Map of longwall panel $\mathrm{N}-17$ in seam 328/1

Source: [15].
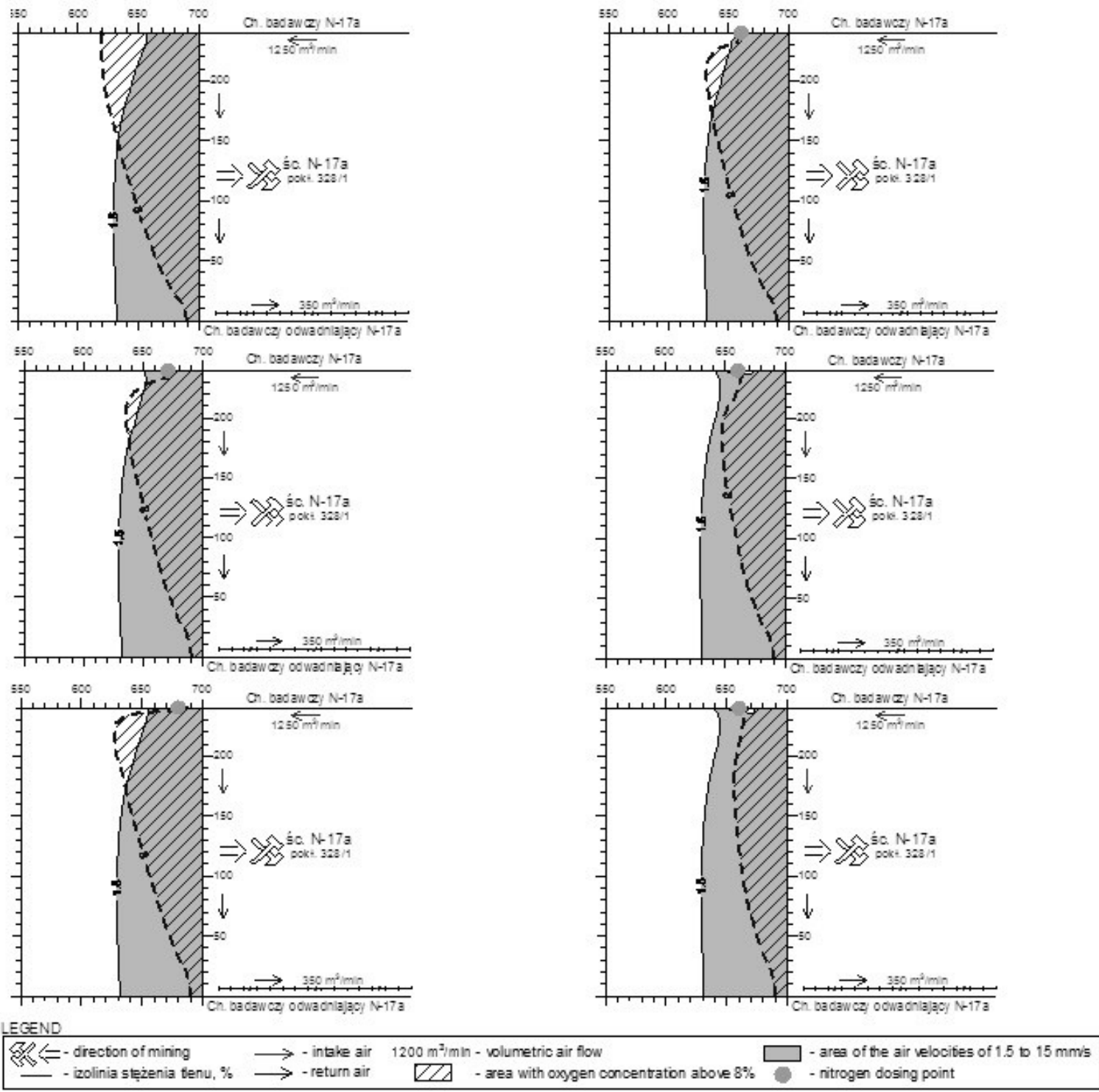

Fig. 4 The results of computer simulation of the distribution of oxygen concentration in the goaf of longwall $\mathrm{N}-17$, with the marked area of the air velocities of 1.5 to $15 \mathrm{~mm} / \mathrm{s}$ :

a) without injections of nitrogen, b) after injections of $20 \mathrm{~m}^{3} / \mathrm{min}$ nitrogen $30 \mathrm{~m}$ from goaf line, c) after injections of $30 \mathrm{~m} / \mathrm{min}$ nitrogen $20 \mathrm{~m}$ from goaf line, d) after injections of $10 \mathrm{~m}^{3} / \mathrm{min}$ nitrogen $40 \mathrm{~m}$ from goaf line, e) after injections of $20 \mathrm{~m}^{3} / \mathrm{min} \mathrm{nitrogen} 40 \mathrm{~m}$ from goaf line, f) after injections of $30 \mathrm{~m}^{3} / \mathrm{min}$ nitrogen $40 \mathrm{~m}$ from goaf line 
Proposed rating scale of the effectiveness of inertisation

\begin{tabular}{|c|c|c|}
\hline $\begin{array}{l}\text { Reduction in the area of the intersection with oxygen } \\
\text { concentration above } 8 \% \text { and where air flow velocity ranges } \\
\text { from } 1.5 \text { to } 15 \mathrm{~mm} / \mathrm{s} \text {, in comparison with the state before } \\
\text { inertisation. }\end{array}$ & $\begin{array}{l}\text { Estimation } \\
\text { of the effectiveness } \\
\text { of inertisation }\end{array}$ & Notes \\
\hline$\%$ & - & - \\
\hline$<80,100>$ & very good & \multirow{4}{*}{$\begin{array}{l}\text { no activity } \\
\text { change the location of the point of injecting } \\
\text { nitrogen and/or nitrogen flow } \\
\text { change the location of the point of injecting } \\
\text { nitrogen and/or nitrogen flow } \\
\text { change the location of the point of injecting } \\
\text { nitrogen and/or nitrogen flow }\end{array}$} \\
\hline$<50,80)$ & good & \\
\hline$<20,50)$ & satisfactory & \\
\hline$<0,20)$ & unsatisfactory & \\
\hline
\end{tabular}

Source: [16].

For the data presented above, variant computer simulations of the distribution of oxygen concentration in longwall goaf $\mathrm{N}-17 \mathrm{a}$ and the distribution of air velocity in goaf were conducted. The calculations were conducted for different volumetric flow rates of nitrogen ranging from $10 \mathrm{~m}^{3} / \mathrm{min}$ to $30 \mathrm{~m}^{3} / \mathrm{min}$. Different points of injecting inert gas from 20 to $70 \mathrm{~m}$ from goaf line were taken into consideration. The computer programme presented in work [14] was used for those calculations.

Figures $4 a-f$ presents the selected results of conducted computer simulations of the distribution of oxygen concentration in longwall goaf $\mathrm{N}-17$ a with a marked area with air velocity ranging from 1.5 to $15 \mathrm{~mm} / \mathrm{s}$. The variant without inertisation (Fig. 4a) was used as a reference point while estimating the effectiveness of inertisation when inert gas was dosed.

In cases under consideration, the aim to be achieved is the reduction in oxygen concentration below $8 \%$ in the area where air velocity ranges from 1.5 to $15 \mathrm{~mm} / \mathrm{s}$. In the figures $4 a-f$ the area where air concentration is above $8 \%$ was hatched, the isoline of $8 \%$ oxygen concentration was marked with a dark line and dotted line. The area where air flow velocity ranges from 1.5 to $15 \mathrm{~mm} / \mathrm{s}$ was filled. That is why achieving the aim of inertisation consists in such a choice of volumetric flow of inert gas (nitrogen) and the point of injecting gas that the areas with oxygen concentration above $8 \%$ and air velocity ranging from 1.5 to $15 \mathrm{~mm} / \mathrm{s}$ do not overlap.

It must be emphasized that reducing oxygen concentration below $8 \%$ in the whole area where air velocity ranges from 1.5 to $15 \mathrm{~mm} / \mathrm{s}$ may be difficult. Table 1 presents proposals of estimating the effectiveness of inertisation. Inertisation is effective if the intersection of the area with oxygen concentration above $8 \%$ and the area where air flow velocity ranges from 1.5 to $15 \mathrm{~mm} / \mathrm{s}$, in comparison with the state before inertisation, is reduced.

If the criterion of the effectiveness of inertisation is fulfilled, that is the effectiveness of inertisation is at least satisfactory, work on a technical project of inertisation should be started. The aim should be to achieve the effectiveness of inertisation as high as possible. It can be achieved by the change in the location of the point injecting inert gas. If it is not effective, the assumed volumetric flow of inert gas should be increased and computer simulations for different points of dosing increased gas volumes should be conducted. If all possible variants of inertisation have been tried and their effectiveness is not sufficient or satis- factory, inertisation should be given up and other fire prevention methods should be used. When analysing the results of calculations it was concluded that injecting $10 \mathrm{~m}^{3} / \mathrm{min}$ of nitrogen will not ensure the sufficient effectiveness of inertisation. The minimum nitrogen flow rate to be ensured is $20 \mathrm{~m}^{3} / \mathrm{min}$. However, it is recommended to ensure a greater inert gas flow.

The conducted calculations took into consideration injecting nitrogen up to $30 \mathrm{~m}^{3} / \mathrm{min}$. According to computer simulations, fire hazard is highly reduced with such a volumetric inert gas flow. Although the area with favourable conditions for coal spontaneous combustion was reduced, fire hazard was not totally eliminated.

When determining volumetric flow rate of dosed nitrogen, technical possibilities of producing and supplying nitrogen must be considered. Therefore, the example above took into consideration nitrogen flow of maximum $30 \mathrm{~m}^{3} / \mathrm{min}$.

Different locations of inertisation point should be considered in order to use available gas properly. For example, to inert $20 \mathrm{~m}^{3} / \mathrm{min}$ of nitrogen in distance $30 \mathrm{~m}$ from the line of caving (Fig. $4 \mathrm{~b}$ ) it is possible much more reduction in intersection between filed with oxygen concentration above $8 \%$ and field of air velocity ranges from 1.5 to $15 \mathrm{~mm} / \mathrm{s}$, than with inert $30 \mathrm{~m}^{3} / \mathrm{min}$ of nitrogen in the distance $20 \mathrm{~m}$ from the line of caving (Fig. 4c). There is $13 \%$ and $10 \%$, respectively.

On the basis of computer simulations it can be concluded that for each variant under consideration it is most beneficial to inject nitrogen at the distance from 40 to $50 \mathrm{~m}$ from goaf line; that is a recommended distance for injecting nitrogen. Figures $4 d-f$ present cases of dosing different volumetric flows of inert gas at the distance of $40 \mathrm{~m}$ from goaf line.

The area of the intersection, with oxygen concentration above $8 \%$ and where air flow velocity ranges from 1.5 to $15 \mathrm{~mm} / \mathrm{s}$ while injecting $30 \mathrm{~m}^{3} / \mathrm{min}$ of oxygen, was reduced by $31 \%$. When $20 \mathrm{~m}^{3} / \mathrm{min}$ of nitrogen is injected the area will be reduced by $20 \%$, according to the estimating scale assumed before. This kind of inertisation is effective enough. Therefore volumetric flow of nitrogen for longwall $\mathrm{N}-17$ a should be $20 \mathrm{~m}^{3} / \mathrm{min}$.

Work on technical project of inertisation can be started when we already know what the required volumetric flow of inert gas is as well as the distance of the injection point from longwall goaf. 


\section{SUMMARY}

1. It is necessary to determine the point of the injection of inert gas and its quantity in order to improve the effectiveness of inertisation.

2. The obtained criteria for estimating the effectiveness of inertisation can be helpful when taking a decision regarding the choice of a prevention method.

3. It must be remembered that inertisation can help to reduce self-combustion risk in goaf and it is necessary to take into consideration possibilities of dosing inert gas, already when planning mining.

The article was written within Statutes Research AGH No. 11.11.100.774

\section{REFERENCES}

[1] P. Buchwald. „Określenie podstawowego kryterium i parametrów oceny skuteczności zastosowania azotu w prewencji pożarów endogenicznych w przestrzeniach otamowanych", in Górnictwo i Geologia, tom 4, z. 3, 2009, pp. 31-39.

[2] CSRG. Zasady prowadzenia akcji ratowniczych i prac profilaktycznych z wykorzystaniem gazów inertnych, Centralna Stacja Ratownictwa Górniczego S.A., Bytom, July 2002.

[3] CSRG. Zasady prowadzenia akcji ratowniczych i prac profilaktycznych z wykorzystaniem gazów inertnych, Centralna Stacja Ratownictwa Górniczego S.A., Bytom, March 2008.

[4] J.D. Davis and J.F. Byrne. „Influence of moisture on the spontaneous heating of coal", in Industrial and Engineering Chemistry, vol. 18(3), 1926, pp. 233-236.

[5] Z. Maciejasz and F. Kruk. Pożary podziemne w kopalniach. Część l, Katowice: Wydawnictwo Śląsk, 1977.

[6] T.N. Mason and F.V. Tideswell. „Gob fires, part 2 - The revival of heatings by inleakage of air", in Paper of Safety in Mines Research Board, no. 76, 1993.

Prof. dr hab. inż. Nikodem Szlązak, dr inż. Kazimierz Piergies AGH University of Science and Technology,

Al. Mickiewicza 30, 30-059 Kraków, POLAND

e-mail: szlazak@agh.edu.pl

piergies@agh.edu.pl
[7] J. Szlązak. „Wpływ uszczelnienia chodników przyścianowych na przepływ powietrza przez zroby", Ph.D. dissertation, Akademia Górniczo-Hutnicza, Wydział Górniczy, Kraków, 1980.

[8] J. Szlązak. Metody obliczania rozpływu powietrza $i$ rozkładu stężenia metanu w zrobach ścian zawałowych. Przykłady wykorzystania, Gliwice: Wydawnictwo Politechniki Śląskiej, 2010.

[9] N. Szlązak. „Ocena zagrożenia pożarowego w zrobach ścian zawałowych na podstawie intensywności ich przewietrzania", in Archiwum Górnictwa, tom 35, z. 3, 1990, pp. 339-345.

[10] N. Szlązak, D. Obracaj and K. Piergies. „Ogólne zasady inertyzacji azotem zrobów czynnej ściany zawałowej”, in Górnictwo i Geoinżynieria, tom 35, z. 4, 2011, pp. 131-142.

[11] N. Szlązak, D. Obracaj and K. Piergies. „Podstawy inertyzacji zrobów ścian zawałowych w kopalniach węgla kamiennego", in Wybrane zagrożenia aerologiczne w kopalniach podziemnych i ich zwalczanie, Szlązak N., Kraków: Wydawnictwa AGH, 2011, pp. 239-259.

[12] N. Szlązak and J. Szlązak. Filtracja powietrza przez zroby ścian zawałowych w kopalniach węgla kamiennego, Kraków: Wydawnictwa AGH, 2005.

[13] N. Szlązak, S. Yuan and D. Obracaj. Zagrożenie pożarowe w kopalniach węgla kamiennego i metody jego oceny. Kraków: Uczelniane Wydawnictwa NaukowoDydaktyczne AGH, 2005.

[14] K. Piergies. „Ocena skuteczności inertyzacji zrobów ścian zawałowych w kopalniach węgla kamiennego", Ph.D. dissertation, Akademia Górniczo-Hutnicza, Wydział Górnictwa i Geoinżynierii, Kraków, 2015.

[15] Projekt techniczny eksploatacji pokładu 328/1 ścianq N-17a. 2014. [unpublished] 